\title{
Comparing the Effects of Intracellular and Extracellular Magnetic Hyperthermia on the Viability of BxPC-3 Cells
}

\author{
Gary Hannon ${ }^{1}\left(\mathbb{D}\right.$, Anna Bogdanska $^{1}$, Yuri Volkov ${ }^{1,2,3,4, *(\mathbb{D})}$ and Adriele Prina-Mello ${ }^{1,2,3, *(\mathbb{D})}$ \\ 1 Nanomedicine and Molecular Imaging Group, Trinity Translational Medicine Institute, Dublin 8, Ireland; \\ hannonga@tcd.ie (G.H.); abogdans@tcd.ie (A.B.) \\ 2 Laboratory of Biological Characterization of Advanced Materials (LBCAM), Trinity Translational Medicine \\ Institute, Trinity College Dublin, Dublin 8, Ireland \\ 3 Advanced Materials and Bioengineering Research (AMBER) centre, CRANN institute, Trinity College \\ Dublin, Dublin 2, Ireland \\ 4 Department of Histology, Cytology and Embryology, First Moscow State Sechenov Medical University, \\ Moscow 119992, Russia \\ * $\quad$ Correspondence: YVOLKOV@tcd.ie (Y.V.); PRINAMEA@tcd.ie (A.P.-M.); Tel.: +353-1896-3259 (A.P.-M.)
}

Received: 6 February 2020; Accepted: 22 March 2020; Published: 24 March 2020

\begin{abstract}
Magnetic hyperthermia involves the use of iron oxide nanoparticles to generate heat in tumours following stimulation with alternating magnetic fields. In recent times, this treatment has undergone numerous clinical trials in various solid malignancies and subsequently achieved clinical approval to treat glioblastoma and prostate cancer in 2011 and 2018, respectively. However, despite recent clinical advances, many questions remain with regard to the underlying mechanisms involved in this therapy. One such query is whether intracellular or extracellular nanoparticles are necessary for treatment efficacy. Herein, we compare the effects of intracellular and extracellular magnetic hyperthermia in BxPC-3 cells to determine the differences in efficacy between both. Extracellular magnetic hyperthermia at temperatures between $40-42.5^{\circ} \mathrm{C}$ could induce significant levels of necrosis in these cells, whereas intracellular magnetic hyperthermia resulted in no change in viability. This led to a discussion on the overall relevance of intracellular nanoparticles to the efficacy of magnetic hyperthermia therapy.
\end{abstract}

Keywords: magnetic hyperthermia; iron oxide nanoparticles; magnetic nanoparticles; cancer

\section{Introduction}

Iron oxide nanoparticles (IONP) have been researched extensively in a wide range of oncological applications [1,2]. One such promising field is magnetic hyperthermia [3]. This treatment involves the use of IONP to generate heat in tumours following stimulation with alternating magnetic fields (AMF). Under the influence of AMF, IONP rapidly change their polarity resulting in elevations of heat by way of hysteresis losses and relaxation losses [4,5]. At sufficiently small sizes ( $<50 \mathrm{~nm})$, IONP consist of single magnetic domains and, in this case, heat is generated primarily through Nèel and Brownian relaxation [6-8]. Single domain IONP can also exhibit superparamagnetic properties characterized by thermally-driven inversions in their internal magnetisation $[7,9]$. Superparamagnetic IONP are ideal materials for magnetic hyperthermia as they have large magnetic moments that align uniformly to the applied AMF generating a substantial saturation magnetization, all while having a recorded average remnant magnetization of zero when the field is removed. This allows for a controlled thermal treatment that is favourable for in vivo applications $[10,11]$. 
Significant advances have been made in the last two decades with regards to the use of superparamagnetic IONP to treat cancer through magnetic hyperthermia. Since Gilchrist's foundational work in this field in the 1950s and 60s [12,13], IONP design has improved to maximise biocompatibility while enhancing heating performance. Additionally, a wealth of in vivo efficacy studies and clinical trials have confirmed the huge potential of this treatment, which has led to the clinical approval of Nanotherm $₫$, the first IONP to achieve regulatory approval for treating cancer with magnetic hyperthermia $[5,14,15]$. Despite these advances, many questions related to the underlying mechanisms of this therapy remain. One such question is the role that intracellular and extracellular IONP play in this therapy and whether one or both are necessary for treatment efficacy. Many papers have sought to functionalise IONP with targeting agents to improve uptake into cancer cells and enhance treatment efficacy; however, these efforts have generated mixed results $[16,17]$. Herein, we investigate the effects of intracellular and extracellular magnetic hyperthermia with BxPC-3 pancreatic adenocarcinoma cell line. Extracellular magnetic hyperthermia at temperatures of $40-42.5^{\circ} \mathrm{C}$ showed effective induction of necrosis in these cells whereas intracellular magnetic hyperthermia demonstrated no therapeutic effect, leading to questions on its true relevance in the overall contribution to treatment efficacy.

\section{Materials}

Unless otherwise stated, all materials used were purchased from Sigma Aldrich, Wicklow, Ireland. The superparamagnetic IONP used in this study were fluidMAG/C11-D magnetite nanoparticles coated in a starch matrix and supplied by Chemicell, GmbH (Berlin, Germany) as part of the NoCanTher project (grant agreement no. 685795). These nanoparticles have been autoclaved by the suppliers to ensure sterility. The material is used as received.

\section{Methods}

\subsection{Characterisation}

The hydrodynamic diameter of the nanoparticles was assessed using nanoparticle tracking analysis (NS500 Nanosight, Malvern-Panalytical, Malvern, UK) according to protocols published previously $[18,19]$, and now an established protocol for the EUNCL (EU Nanomedicine Characterisation Laboratory) [20]. These results were confirmed with dynamic light scattering (DLS) measurements (Malvern Nano- ZS, Malvern-Panalytical, Malvern, UK), following the EUNCL protocol for DLS size analysis [21]. Zeta potential data was provided by the nanoparticle supplier (at pH 7), Chemicell. For determining the dry diameter of the nanoparticles, transmission electron microscopy was used. Here, nanoparticles were diluted 1 in 1000 from the stock $(100 \mathrm{mg} / \mathrm{mL})$ in double distilled water $\left(\mathrm{ddH}_{2} 0\right)$ and adhered to Lacey carbon grids (AGAR Scientific, Stansted, UK). Images were taken using the JOEL 2100 (JOEL, Tokyo, Japan) at an acceleration of $200 \mathrm{kV}$ and a beam current of 100-110 $\mu \mathrm{A}$. The longest diameter of 200 individual nanoparticles was measured using ImageJ software to generate a size distribution (for a description of hydrodynamic size, zeta potential and dry size analysis, see Figure S1).

\subsection{Iron Quantification}

Iron concentration was determined by atomic absorption spectroscopy (SpectraAA-200, Varian, California, CA, USA). Here the nanoparticles were dissolved in $1 \mathrm{~mL} 67-69 \%$ trace-element nitric acid (Fisher, Altrincham, UK) at a concentration of $125 \mu \mathrm{g} / \mathrm{mL}$ of nanoparticle and heated to $60^{\circ} \mathrm{C}$ for four hours. The nanoparticles were then diluted in trace-elemental water (Fisher, Altrincham, UK) for analysis. A standard curve between $0-2.5 \mathrm{mg} / \mathrm{L}$ of iron was generated, and the concentration of the nanoparticles was determined from the average of three readings.

\subsection{Heating Performance}

The heating efficiency of these nanoparticles in response to an AMF was measured using a Five Celes inductor system (Five Celes, Lautenbach, France). This system uses a six-turn, moulded solenoid 
coil with an internal diameter of $71 \mathrm{~mm}$. In this experiment, the nanoparticles were dispersed in $100 \mu \mathrm{L}$ of double distilled water $\left(\mathrm{ddH}_{2} \mathrm{O}\right)$ at a nanoparticle concentration of $5 \mathrm{mg} / \mathrm{mL}(368 \mu \mathrm{g} \mathrm{Fe} / \mathrm{mL})$ and exposed to $35 \mathrm{mT}$, at a frequency of $92 \mathrm{kHz}$ (parameters used for in vitro magnetic hyperthermia) for 60 s. Temperature changes were monitored using Optoconßfiber optic temperature sensors (Optoconß, Dresden, Germany) with an accuracy of $\pm 0.2^{\circ} \mathrm{C}$. From these temperature changes, specific absorbance rate (SAR) and intrinsic loss power (ILP) were calculated as reported in Kallumadil et al. [22].

\subsection{In Vitro Cytotoxicity}

BxPC-3 cells (ATCC, CRL-1687; Pancreatic adenocarcinoma of a female human aged 61) were cultured at $37{ }^{\circ} \mathrm{C}$ and $5 \% \mathrm{CO}_{2}$ in RPMI 1640 media supplemented with $10 \%$ FBS and $1 \%$ penicillin-streptomycin (Invitrogen, Altrincham, UK) at 10,000 U/mL and 10,000 $\mu \mathrm{g} / \mathrm{mL}$ respectively. Cells were seeded at 10,000 cells/well in a 96 well plate for $24 \mathrm{~h}$. The cells were then washed with PBS and treated with either nanoparticles $(12.5,25,50,100$, and $200 \mu \mathrm{g} / \mathrm{mL} ; 200 \mu \mathrm{g} / \mathrm{mL}$ of nanoparticle corresponded to $147 \mu \mathrm{g} \mathrm{Fe} / \mathrm{mL}$ ), tacrine at $100 \mu \mathrm{M}$ (positive control for organelle damage [23]), valinomycin at $120 \mu \mathrm{M}$ (positive control for membrane damage [24,25]), or media alone (untreated) for $72 \mathrm{~h}$. Following treatment, the cells were washed three times with PBS to remove extracellular nanoparticles and stained with $50 \mu \mathrm{L}$ of Lysotrackerßred (acidic organelle stain) and YO-PROß-1 (membrane permeability stain) at $3.5 \mu \mathrm{L}$ and $0.35 \mu \mathrm{L}$ per $\mathrm{ml}$ of media respectively for $30 \mathrm{~min}$ at room temperature (stains supplied by Thermo scientific, Altrincham, UK and are described in Table 1). Lysotracker ${ }^{\circledR}$ red stains acidic organelles, with increases in intensity corresponding to $\mathrm{pH}$, and indicative of nanoparticle localisation into lysosomes. Decreases in intensity, however, is a marker for lysosomal damage [26,27]. YO-PROß-1 is a green dye that measures cell membrane permeability; its localisation into the nucleus is used as a measure of cytotoxicity [27]. After staining for $30 \mathrm{~min}$, the dyes are removed, and the cells are fixed with $100 \mu \mathrm{L}$ of $3.7 \%$ formaldehyde for 20 min at room temperature. Following fixation, $0.5 \mu \mathrm{L}$ of Hoechst $33342 / \mathrm{mL}$ in wash buffer is added to each well at $100 \mu \mathrm{L}$ for $10 \mathrm{~min}$. After two subsequent washes, the cells could be imaged. Cytell automated imaging system (GE Healthcare, Buckinghamshire, UK) was used to record automated images of seven fixed fields for each well. These images were analysed through high content screening analysis via InCell Investigator software (GE Healthcare, Buckinghamshire, UK) and intensity and morphology values for cell count, nuclear intensity, and organelle intensity were obtained and compared against untreated cells as measures of cytotoxicity.

Table 1. Description of each stain used for high content screening analysis

\begin{tabular}{ccc}
\hline Stain & Excitation/Emission $\mathbf{( n m )}$ & Stock Concentration \\
\hline Lysotrackerßred & $577 / 590$ & $1 \mathrm{mM}$ \\
YO-PROß-1 & $491 / 509$ & $1 \mathrm{mM}$ \\
Hoechst 33342 & $350 / 461$ & $16.2 \mathrm{mM}$ \\
\hline
\end{tabular}

\subsection{Cell Uptake and Prussian Blue Staining}

To quantify the levels of nanoparticle internalised into the cells, $1 \times 10^{5}$ cells/well were seeded for $24 \mathrm{~h}$ in a 12 well plate. The cells were then treated with $200 \mu \mathrm{g} / \mathrm{mL}$ of nanoparticles for $24 \mathrm{~h}$. After this time, the cells were washed with PBS, detached with trypLE and washed twice more with PBS and centrifugation steps (1000 rpm -at 94 RCF- for $5 \mathrm{~min}$ ). Finally, the cells were counted using trypan blue staining and dissolved in 67-69\%, trace-element nitric acid (Fisher, Altrincham, UK) at $60{ }^{\circ} \mathrm{C}$ for four hours for subsequent inductively coupled plasma-optical emission spectrometry (ICP-OES) analysis (Liberty 150, Varian, California, CA, USA). For this measurement, each treatment group is pooled within each experiment (five experiments in triplicate) to generate enough iron to be detectable by the instrument. The solution is then made up to $5 \mathrm{~mL}$ in trace-element water (Fisher, Altrincham, UK). ICP-OES was performed on these pooled samples as well as six iron standards in duplicate (from 0-2.5 mg/L). To complement this data, Prussian blue staining (iron- specific stain) was additionally 
performed to provide representative images of this iron uptake and identify where the nanoparticles are localised. The experiment was performed as before except, following $24 \mathrm{~h}$ treatment with IONP, the cells were washed three times with PBS, fixed with $4 \%$ formaldehyde for $20 \mathrm{~min}$ at room temperature, washed again as before, stained $1: 1$ with $4 \% \mathrm{HCl}$ and $4 \%$ potassium ferrocyanide, washed again, and finally stained with Eosin for 3 min followed by an additional wash step. Bright field images were then taken using the Lionheart FX microscope (BIOTEK, Bad Friedrichshall, Germany) at 10× magnification.

\subsection{In Vitro Magnetic Hyperthermia}

For this experiment, intracellular hyperthermia was compared against extracellular hyperthermia and a combination of intracellular and extracellular hyperthermia. Intracellular hyperthermia involves the exposure of intracellular IONP to AMF (IONP allowed to internalise for $24 \mathrm{~h}$ ) while extracellular hyperthermia only exposes extracellular IONP (IONP added to the cell media directly before) to AMF. Intracellular and extracellular hyperthermia contains both. A summary of this experiment is demonstrated in Figure 1 below. BxPC-3 cells were seeded at $1 \times 10^{5}$ cells/well in a 12 well plate. After $24 \mathrm{~h}$, cells to be treated with intracellular nanoparticles alone, intracellular hyperthermia, intracellular and extracellular nanoparticles alone, or intracellular and extracellular hyperthermia were treated with $200 \mu \mathrm{g} / \mathrm{mL}$ of nanoparticles. At $48 \mathrm{~h}$, cells are treated with magnetic hyperthermia. Here, the cells are washed with PBS, detached with trypLE and transferred into $1.5 \mathrm{~mL}$ Eppendorf tubes. They are then washed again in PBS through a centrifugation step and redispersed in $100 \mu \mathrm{L}$ of either media (for intracellular hyperthermia or magnetic field alone), or $500 \mu \mathrm{g}$ of nanoparticle in $100 \mu \mathrm{L}$ media (for extracellular nanoparticles alone, extracellular hyperthermia, intracellular and extracellular nanoparticles alone, or intracellular and extracellular hyperthermia). For the cells exposed to $500 \mu \mathrm{g}$ of nanoparticle alone, they are kept at $37^{\circ} \mathrm{C}$ for $30 \mathrm{~min}$. For the cells exposed to the magnetic field, the tubes are wrapped in parafilm and a sterile fibre optic temperature probe (washed in $70 \%$ ethanol) is pierced through the film into the cells and media. A water bath keeps the cells at $37 \pm 1{ }^{\circ} \mathrm{C}$ before the AMF is applied. The cells are then exposed to a field of $35 \mathrm{mT}$ at a frequency of $92 \mathrm{kHz}$. This field and frequency enabled the extracellular nanoparticles to reach therapeutic temperatures while also having no effect on cells alone (see results). Once the temperature in the media of the cells treated with extracellular nanoparticles reaches $40^{\circ} \mathrm{C}$ (within 60-120 s), the timer is started and the cells are exposed to temperatures between $40-42.5^{\circ} \mathrm{C}$ or 'mild hyperthermia' $[28,29]$ for $30 \mathrm{~min}$. Following AMF exposure, the cells are washed three times with their original RPMI media (centrifuged at $1000 \mathrm{rpm}$ for $5 \mathrm{~min}$ ) and placed back into a 12 well plate. After $24 \pm 1 \mathrm{~h}$, the media in each well was added to $1.5 \mathrm{~mL}$ tubes and cells are detached with TrypLE and added to their respective media to be stained for flow cytometry analysis (see Section 3.5). The cells are subsequently analysed by flow cytometry to identify populations or apoptotic and necrotic cells. As reported in Blanco-Andujar et al. [30] and Ludwig et al [31], the effects of magnetic hyperthermia on viability are the most reflective in the first $24 \mathrm{~h}$, with changes in viability between 24 and $48 \mathrm{~h}$ proving to be negligible.

\subsection{Apoptosis/Necrosis Detection}

To detect levels of apoptosis and necrosis in the BxPC-3 cells after treatment, APC-Annexin V and 7-AAD stains (BioLegend, London, UK) were used as the nanoparticles were shown not to interfere in these channels (Figure S2). $24 \mathrm{~h}$ after the exposure to the AMF, the media and detached cells were washed twice with staining buffer and stained with $50 \mu \mathrm{L}$ of APC-Annexin V $(2.5 \mu \mathrm{L} / \mathrm{mL}$ of Annexin binding buffer) for $30 \mathrm{~min}$. After such staining, the cells were washed three times with Annexin binding buffer and redispersed in $2.5 \mu \mathrm{L} / \mathrm{mL}$ of 7-AAD in staining buffer. The cells were then analysed with the FACSCanto II flow cytometer from BD Biosciences, San Jose, CA, USA (10,000 recorded events per treatment) and the data was subsequently analysed via FlowJo 10 and GraphPad Prism 7 software (gating strategy: Figure S3). Positive stain controls for APC-Annexin V were cisplatin treated cells at $50 \mu \mathrm{M}$ for $24 \mathrm{~h}$ and for 7-AAD were $10 \%$ DMSO treated cells for $1 \mathrm{~h}$. 


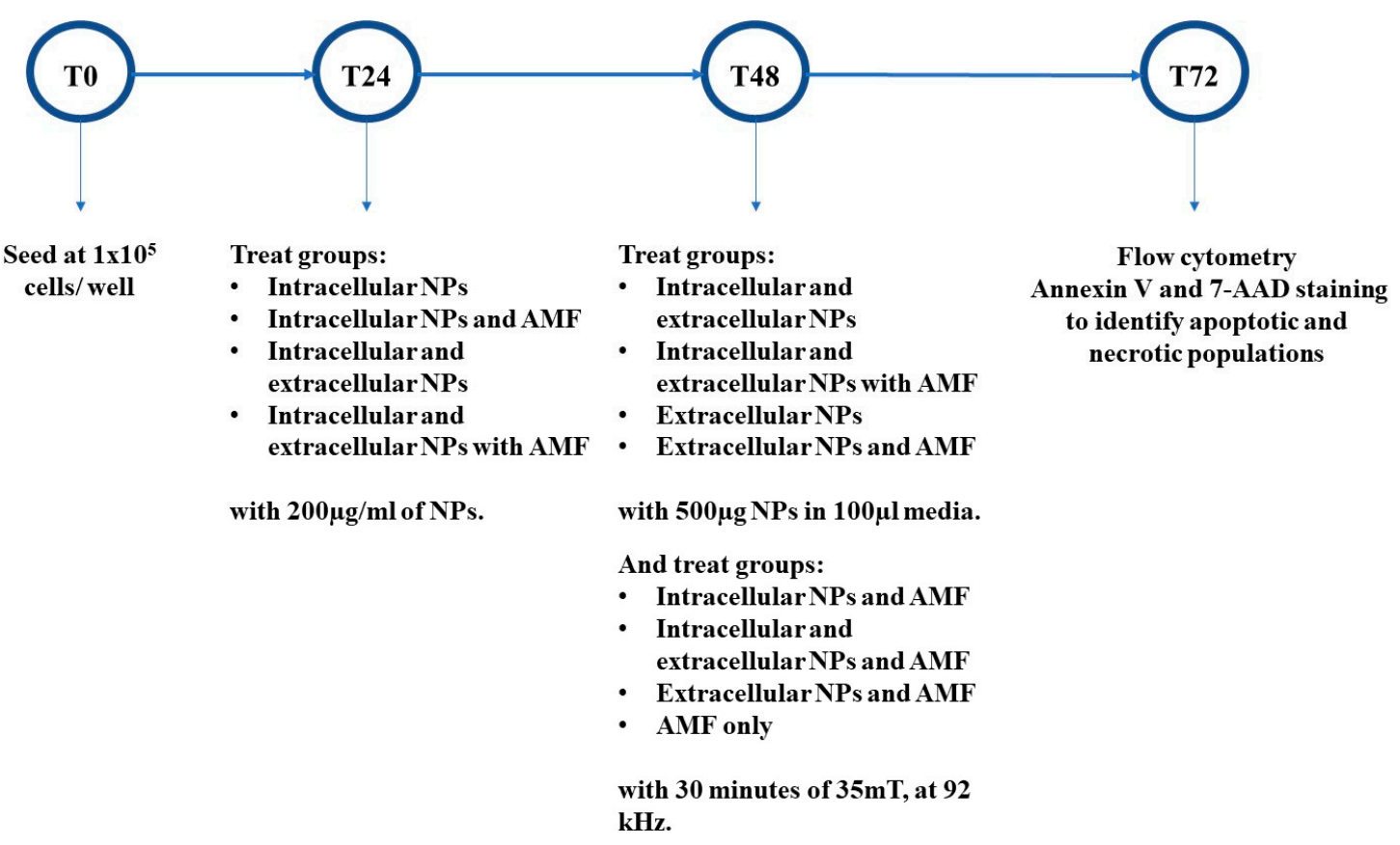

Figure 1. Summary of in vitro magnetic hyperthermia protocol. BxPC-3 cells are seeded at time zero (T0). Cells to contain intracellular nanoparticles are treated with $200 \mu \mathrm{g} / \mathrm{mL}$ at $24 \mathrm{~h}$ (T24). At $48 \mathrm{~h}$ (T48), cells exposed to extracellular nanoparticles are treated with $500 \mu \mathrm{g}$ of nanoparticles in $100 \mu \mathrm{L}$ media, and cells to be treated with magnetic fields, are exposed to $35 \mathrm{mT}$ at $92 \mathrm{kHz}$ for $30 \mathrm{~min}$. Finally, at $72 \mathrm{~h}$ (T72), all treatment groups are stained with annexin V and 7-AAD and analysed by flow cytometry for detection of apoptotic and necrotic cells. Abbreviations: NPs, nanoparticles; AMF, alternating magnetic field.

\subsection{Caspase 3 Activity}

Following apoptosis/necrosis detection by flow cytometry, caspase 3 activity was measured colourimetrically at $405 \mathrm{~nm}$ according to manufacturer's protocol (Abcam ab39401, Cambridge, UK) to distinguish whether the main mechanism of cell death was apoptosis or necrosis. For this analysis, in vitro magnetic hyperthermia was repeated as before in four more experiments. In order to get enough protein for the analysis, each treatment group from two experiments had to be pooled together. For each experiment, BxPC-3 cells were also treated with $50 \mu \mathrm{M}$ of cisplatin for $24 \mathrm{~h}$ as a positive control. $1 \mu \mathrm{g} / \mu \mathrm{L}$ of protein from each treatment group was tested in the assay and results were corrected for total protein concentration (BCA kit, Thermo Scientific, Altrincham, UK). Caspase 3 activity was presented as levels of absorbance at $405 \mathrm{~nm}$ in each treatment group against the untreated.

\subsection{Statistical Analysis}

All statistical analysis was done using GraphPad Prism 7 software. All results are reported as mean \pm standard deviation. High content screening data was analysed via one-way ANOVA followed by Dunnett's test. Apoptosis/Necrosis data was analysed by two-way ANOVA followed by Tukey's test for multiple comparisons. Caspase activation was measured with one-way ANOVA followed by Dunnett's test. Significance was represented by ${ }^{*} p<0.05 ;{ }^{* *} p<0.01 ;{ }^{* * *} p<0.001 ;{ }^{* * *} p<0.0001$.

\section{Results}

\subsection{Nanoparticle Characterization and Heating Performance}

NTA reported a mean size of $100 \pm 2.6 \mathrm{~nm}$, which was confirmed with the closely resembled DLS measurements of $91.2 \mathrm{~nm}(\mathrm{PDI}=0.145)$. DLS measured an average zeta potential of $-21 \pm 5.86 \mathrm{mV}$ at pH 7 (negative charge is due to phosphate groups bound to sugar moieties on the starch coating), while 
TEM images were analysed on ImageJ to determine a mean dry diameter of $11 \pm 3 \mathrm{~nm}$ (based on 200 individual measurements of the largest diameter of each nanoparticle; see Figure S1). Upon exposure to $35 \mathrm{mT}$ at $92 \mathrm{kHz}$ for $60 \mathrm{~s}$, the nanoparticles displayed a SAR of $98 \mathrm{~W} / \mathrm{g}_{\mathrm{Fe}}$ in water, corresponding to an ILP of $1.4 \mathrm{nHm}^{2} / \mathrm{kg}$ (Table 2 and Figure 2). This heating capacity resembles other IONP used for in vitro magnetic hyperthermia in the literature [32-34]. Finally, the nanoparticles contained an average of $0.736 \pm 0.01 \mathrm{mg}$ of iron for every $\mathrm{mg}$ of total nanoparticle.

Table 2. Summary of fluidMAG/C11-D characterization. Summary of characterization data by NTA, DLS, AAS, TEM, and heating capability assessment through SAR and ILP values. Zeta potential was provided by the supplier: Chemicell, $\mathrm{GmbH}$. Values represented as mean \pm standard deviation. Abbreviations: NP, nanoparticle.

\begin{tabular}{cc}
\hline Measured Parameter & Value (Technique) \\
\hline Mean hydrodynamic size & $\begin{array}{c}100.0 \pm 2.6 \mathrm{~nm}(\mathrm{NTA}) \\
91.2 \mathrm{~nm}(\mathrm{DLS})\end{array}$ \\
\hline Nanoparticle number & $0.145(\mathrm{DLS})$ \\
\hline Polydispersity index & $9.48 \times 10^{13} \pm 4.60 \times 10^{12} \mathrm{NP} / \mathrm{mL}(\mathrm{NTA})$ \\
\hline Zeta potential & $-21.0 \pm 5.86 \mathrm{mV}(\mathrm{DLS})$ \\
\hline Mean dry size & $11 \pm 3 \mathrm{~nm}(\mathrm{TEM})$ \\
\hline Specific absorbance rate & $1.4 \mathrm{nHm} / \mathrm{g}_{\mathrm{Fe}} / \mathrm{kg}$ \\
\hline Intrinsic loss power & $0.736 \pm 0.01 \mathrm{mg} \mathrm{Fe} / \mathrm{mg} \mathrm{NP}(\mathrm{AAS})$ \\
\hline Fe content
\end{tabular}
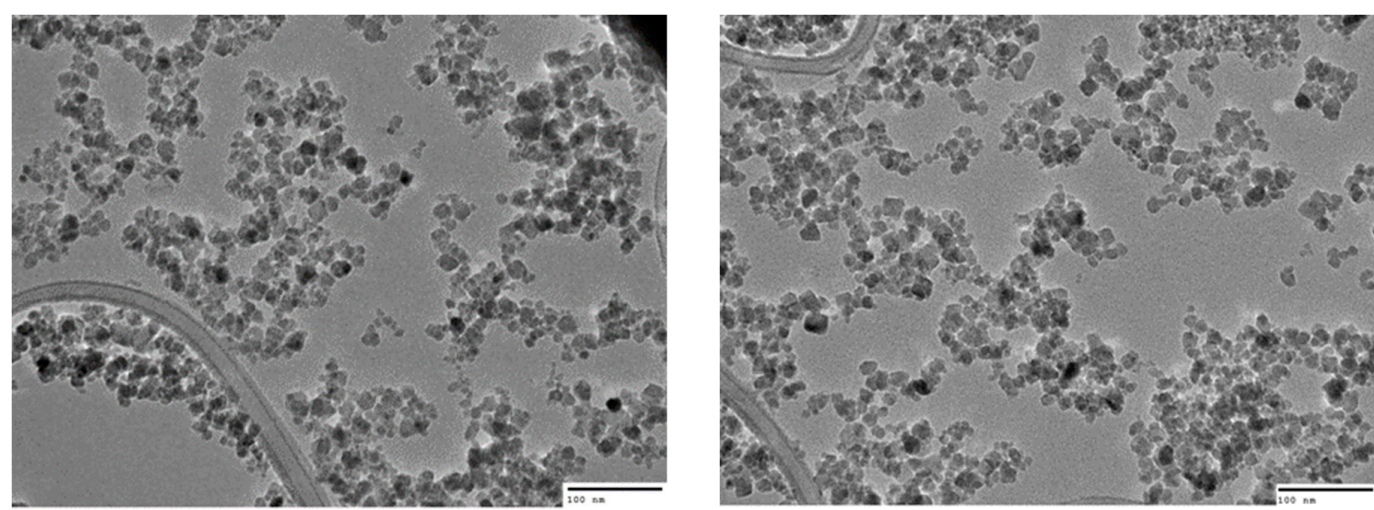

Figure 2. Representative TEM images of fluidMAG/C11-D nanoparticles. Captured with the JOEL 2100 (JOEL, Tokyo, Japan) at an acceleration of $200 \mathrm{kV}$ and a beam current of 100-110 $\mu$ A. Scale bar: $100 \mathrm{~nm}$.

\subsection{In Vitro Cytotoxicity}

Results acquired from the multiparametric analysis of the high content screening experiments showed no significant changes to the cell count, nuclear membrane permeability, or lysosomal permeability parameters after $72 \mathrm{~h}$ treatment of up to $200 \mu \mathrm{g} / \mathrm{mL}$ of nanoparticles against the untreated negative control, while positive controls (tacrine and valinomycin) quantitatively and visibly reduced cell count and lysosomal mass, while increasing nuclear permeability (Figures 3 and 4). 
A

\section{Cell count}

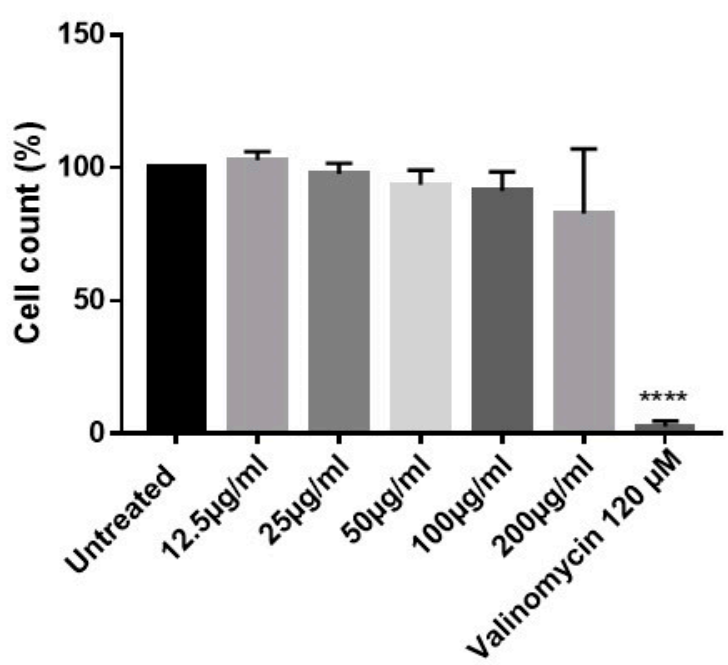

Treatment
B

\section{Nuclear Membrane Permability}

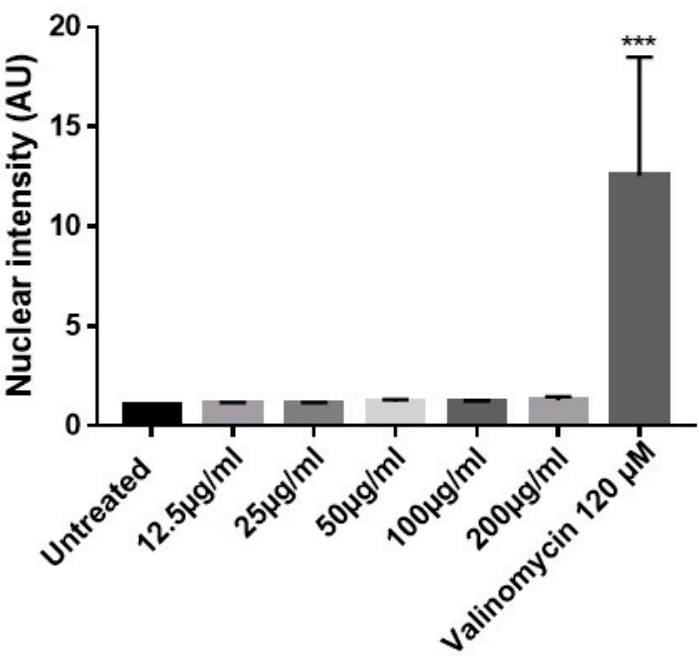

Treatment

C

\section{Lysosomal permeability}

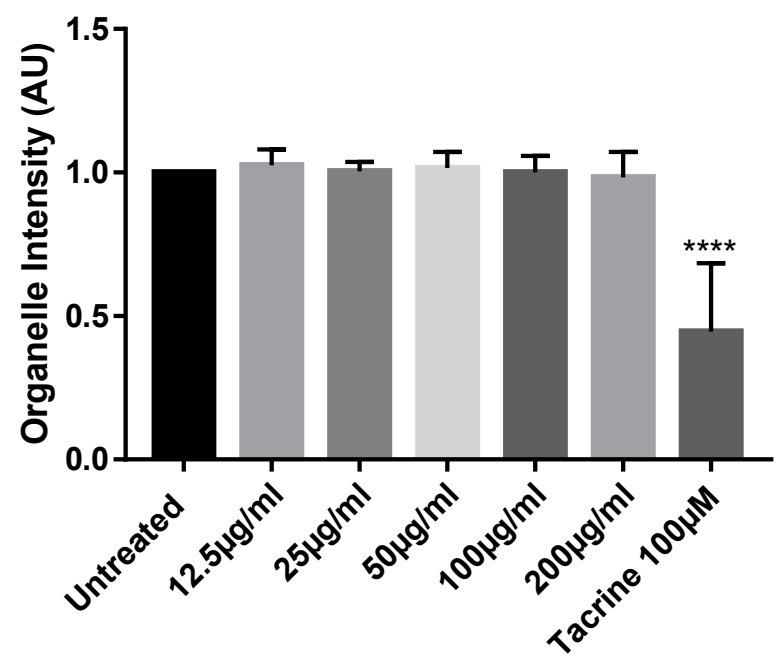

Treatment

Figure 3. Cell count (A), nuclear (B), and organelle intensity (C) plots following high content screening analysis of BxPC-3 cells treated with fluidMAG nanoparticles. Graphs displaying differences in cell count, nuclear intensity, or organelle intensity after treatment with the nanoparticles up to $200 \mu \mathrm{g} / \mathrm{mL}$, tacrine at $100 \mu \mathrm{M}$, and valinomycin at $120 \mu \mathrm{M}$. Cell count values are represented as a percentage of the untreated cells. Membrane permeability and organelle permeability values are normalised against the untreated cells. Results derived from three experiments in triplicate. Significance tested via one-way ANOVA followed by Dunnett's test. Error bars = standard deviation. ${ }^{* * *} \mathrm{p}<0.00011^{* * *} \mathrm{p}<0.001$. 
A. Untreated

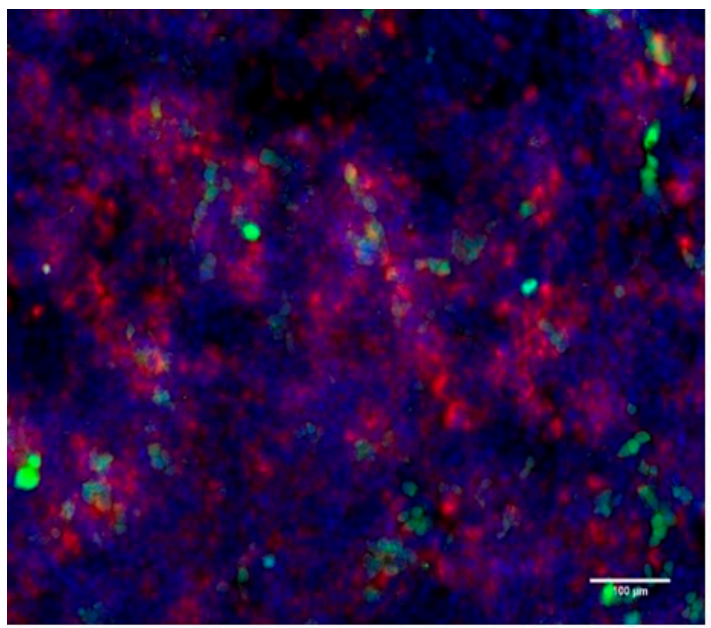

\section{Tacrine $100 \mu \mathrm{M}$}

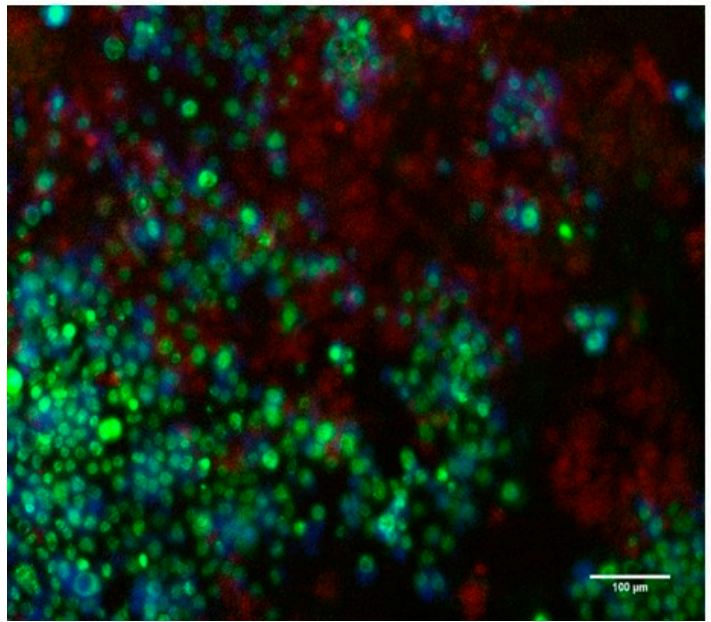

B. $200 \mu \mathrm{g} / \mathrm{mL}$

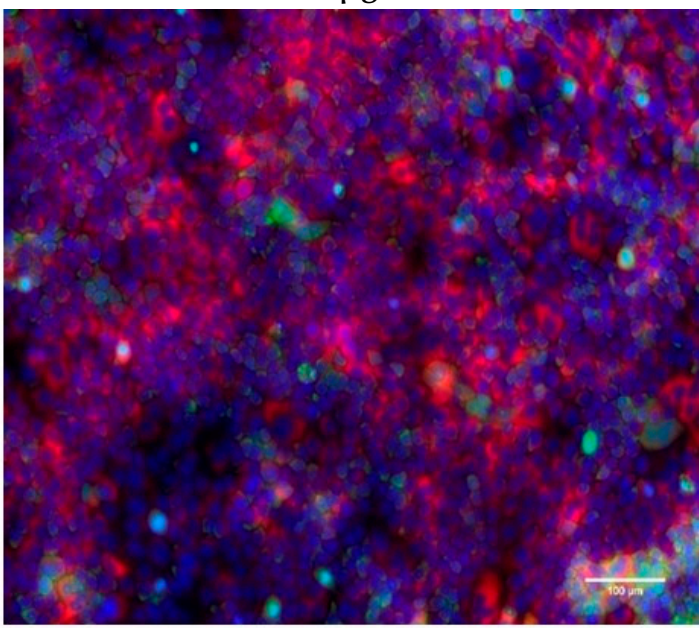

D. Valinomycin $120 \mu \mathrm{M}$

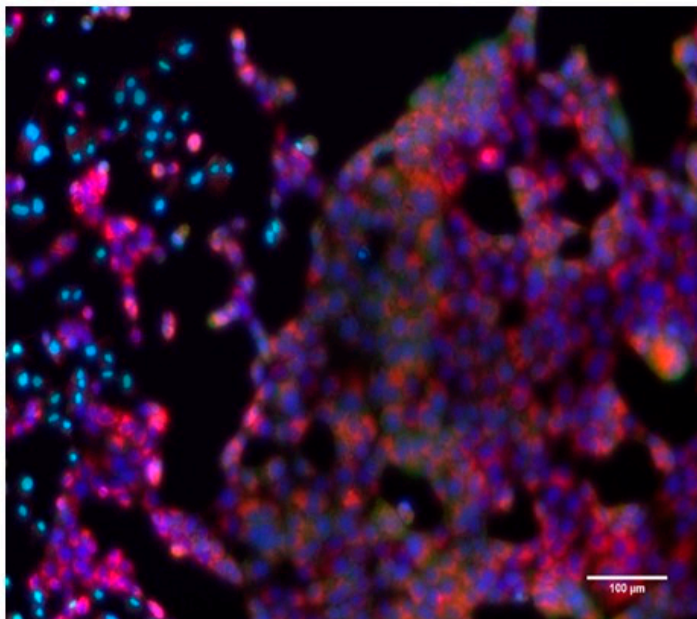

Figure 4. Representative merged images of BxPC-3 cells following treatment. Merged images of untreated (A), $200 \mu \mathrm{g} / \mathrm{mL}$ treated (B), and treated with tacrine (C) and valinomycin (D) positive controls. Scale bar: $100 \mu \mathrm{M}$. Both untreated and $200 \mu \mathrm{g} / \mathrm{mL}$ treated images depict high cell numbers and little green dye located in the nucleus of cells while background levels of red dye consistent between each group. Tacrine and valinomycin-treated cells on the other hand have a visibly lower cell count and both have a high presence of green dye in the nucleus. Additionally, tacrine treated cells have a lower incidence of red dye indicating lysosomal damage to these cells, as previously reported in [23].

\subsection{Cell Uptake and Prussian Blue Staining}

Cellular uptake of the nanoparticles was assessed through qualitative and quantitative measures. ICP-OES identified an average uptake of $12.8 \pm 3.6 \mathrm{pg}$ Fe/cell (12.8 pg Fe corresponds to 16,487 nanoparticles, as measured by NTA) after $24 \mathrm{~h}$. Prussian blue staining confirmed this internalisation and an accumulation of the nanoparticles around the nuclear membrane was consistently observed (Figure 5). 


\section{A. Untreated}

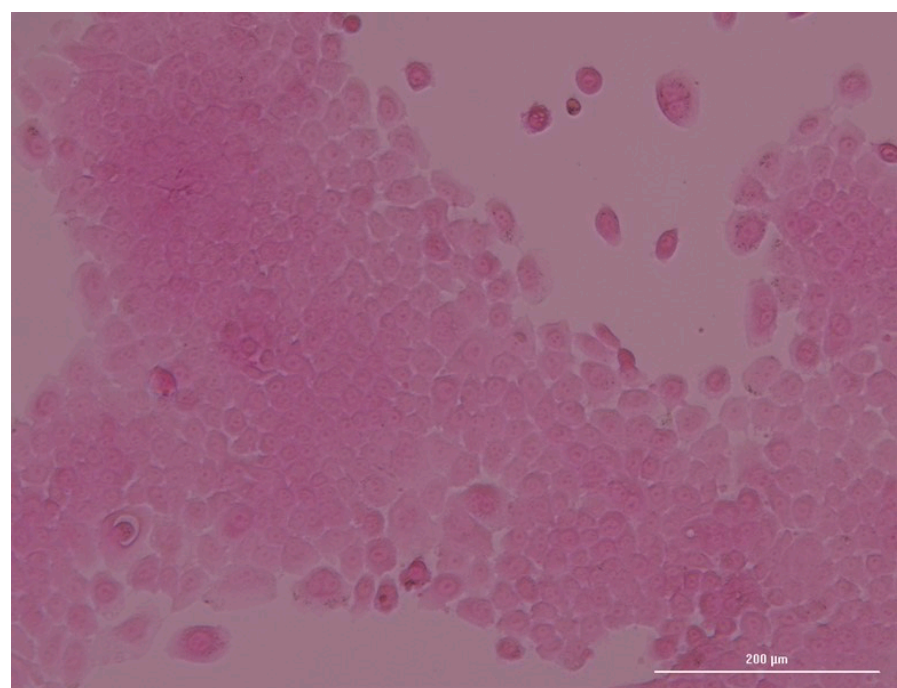

\section{B. $200 \mu \mathrm{g} / \mathrm{mL}$}

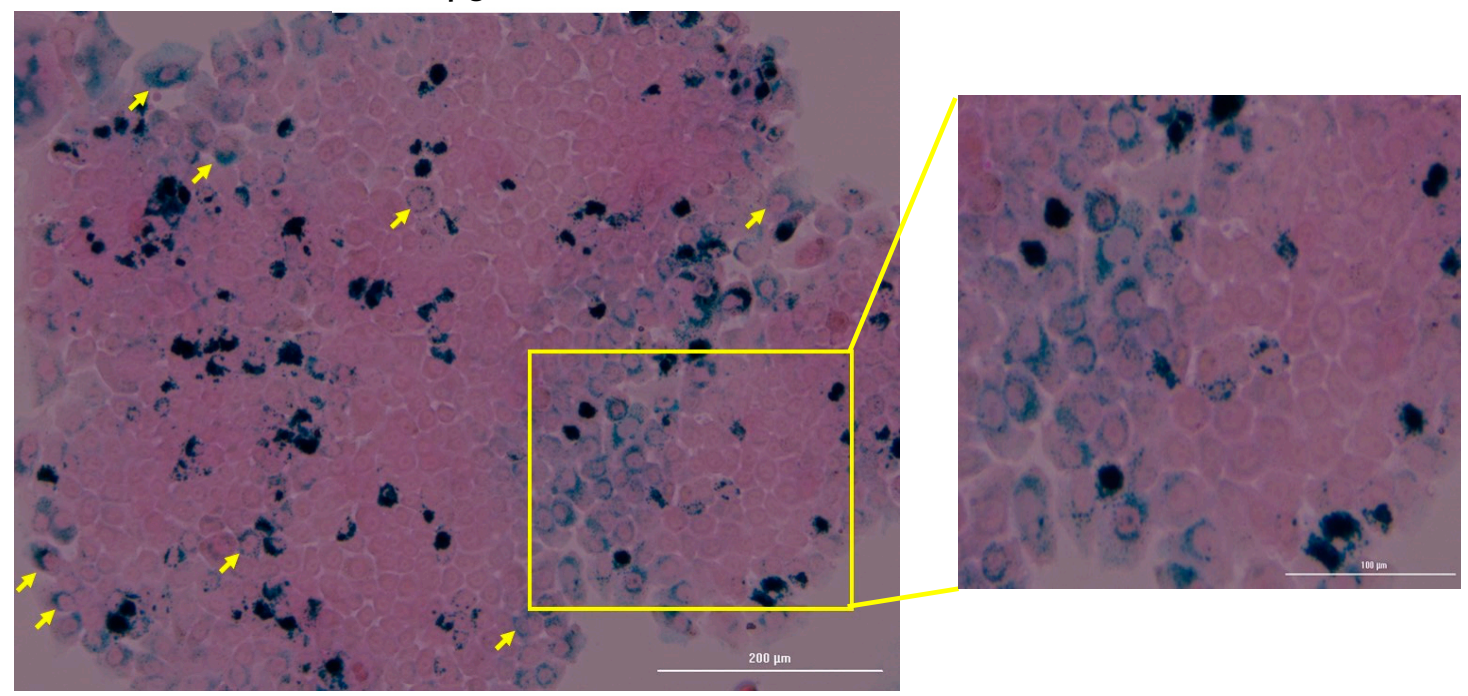

Figure 5. Prussian blue staining of untreated and treated BxPC-3 cells. Untreated cells showed negligible background iron, noted by the absence of blue staining in image (A). The blue staining in image (B) show the nanoparticles tendency to accumulate around the nucleus of the BxPC-3 cells, as highlighted by the yellow arrows and zoomed in image (B). This intracellular accumulation complements the results from the ICP-OES analysis. Scale bar: $200 \mu \mathrm{m}$ for image (A) and (B), and $100 \mu \mathrm{m}$ for zoomed in image (B).

\subsection{Temperature Generation during In Vitro Magnetic Hyperthermia}

Temperature graphs below show successful heating of the nanoparticles when used for extracellular hyperthermia (500 $\mu \mathrm{g}$ IONP in $100 \mu \mathrm{L}$ media) and intracellular and extracellular hyperthermia with temperatures of $41.2 \pm 0.6{ }^{\circ} \mathrm{C}$ being achieved across the entire experiment. No changes in media temperature were seen with intracellular nanoparticles in comparison to cells treated with the magnetic field and media alone. It is worth noting that the cells exposed to AMF alone never reached temperatures above $38^{\circ} \mathrm{C}$ (Figure 6). 
A

\section{Intracellular MH}

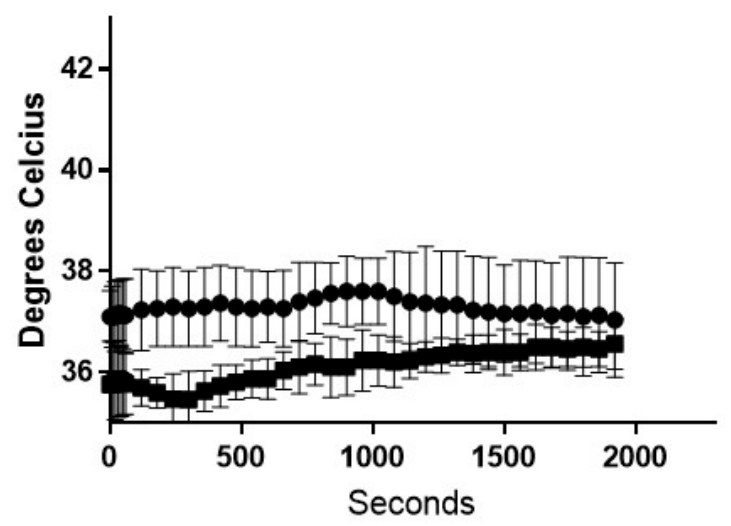

B

\section{Extracellular MH}

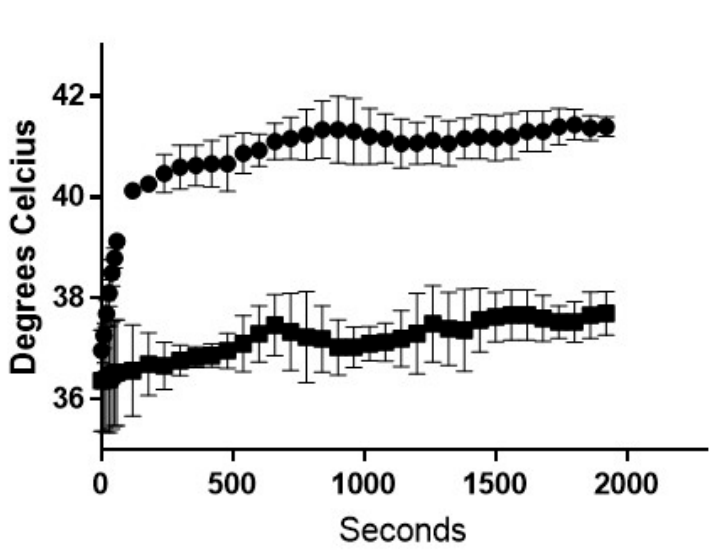

C

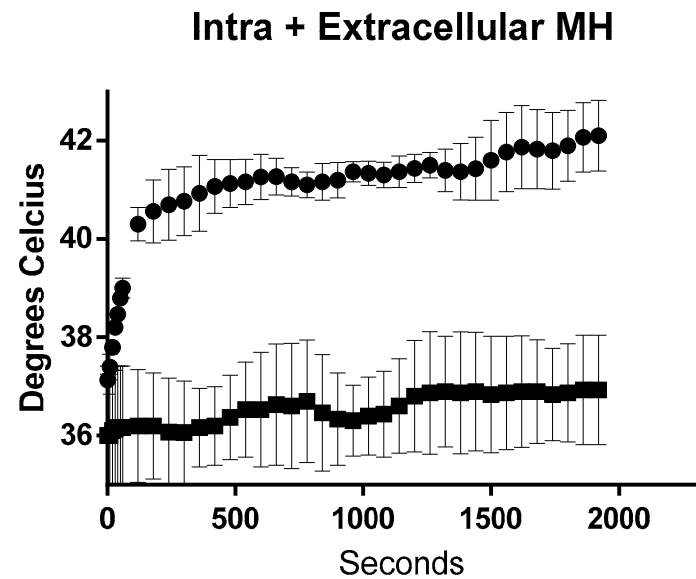

- $\mathrm{NP}+\mathrm{AMF}$

- $\mathrm{AMF}$

Figure 6. Temperature graphs of magnetic hyperthermia with BxPC-3 cells. Intracellular and magnetic field only cells remained at biologically viable temperatures (A). Extracellular nanoparticles successfully generated temperatures required for mild hyperthermia (B) and (C). Abbreviations: NP, nanoparticles; $\mathrm{MH}$, magnetic hyperthermia; AMF, alternating magnetic field.

\subsection{Cell Viability Detection Following Magnetic Hyperthermia}

Following the hyperthermia treatments described previously, the cells were assessed for their viability by flow cytometry after $24 \pm 1 \mathrm{~h}$. Intracellular magnetic hyperthermia displayed no significant effect on the viability of the BxPC-3 cells when compared against the untreated, whereas extracellular magnetic hyperthermia-both alone and in combination with intracellular magnetic hyperthermia-showed significant reductions in cell viability after 30 min treatment. Additionally, the presence of the magnetic field alone had no effect on the cells either. This significant reduction in viability with extracellular magnetic hyperthermia is also observed when compared against the nanoparticles alone; therefore, the nanoparticles by themselves are not inducing this effect, but the whole magnetic hyperthermia treatment (Figure 7). Moreover, heating the BxPC-3 cells with an incubator to $42.5^{\circ} \mathrm{C}$ for 30 min showed no significant effect on viability against untreated cells, confirming that the magnetic hyperthermia treatment as a whole was affecting the cells, and not just the inherent temperature elevation (Figure S4). 
A

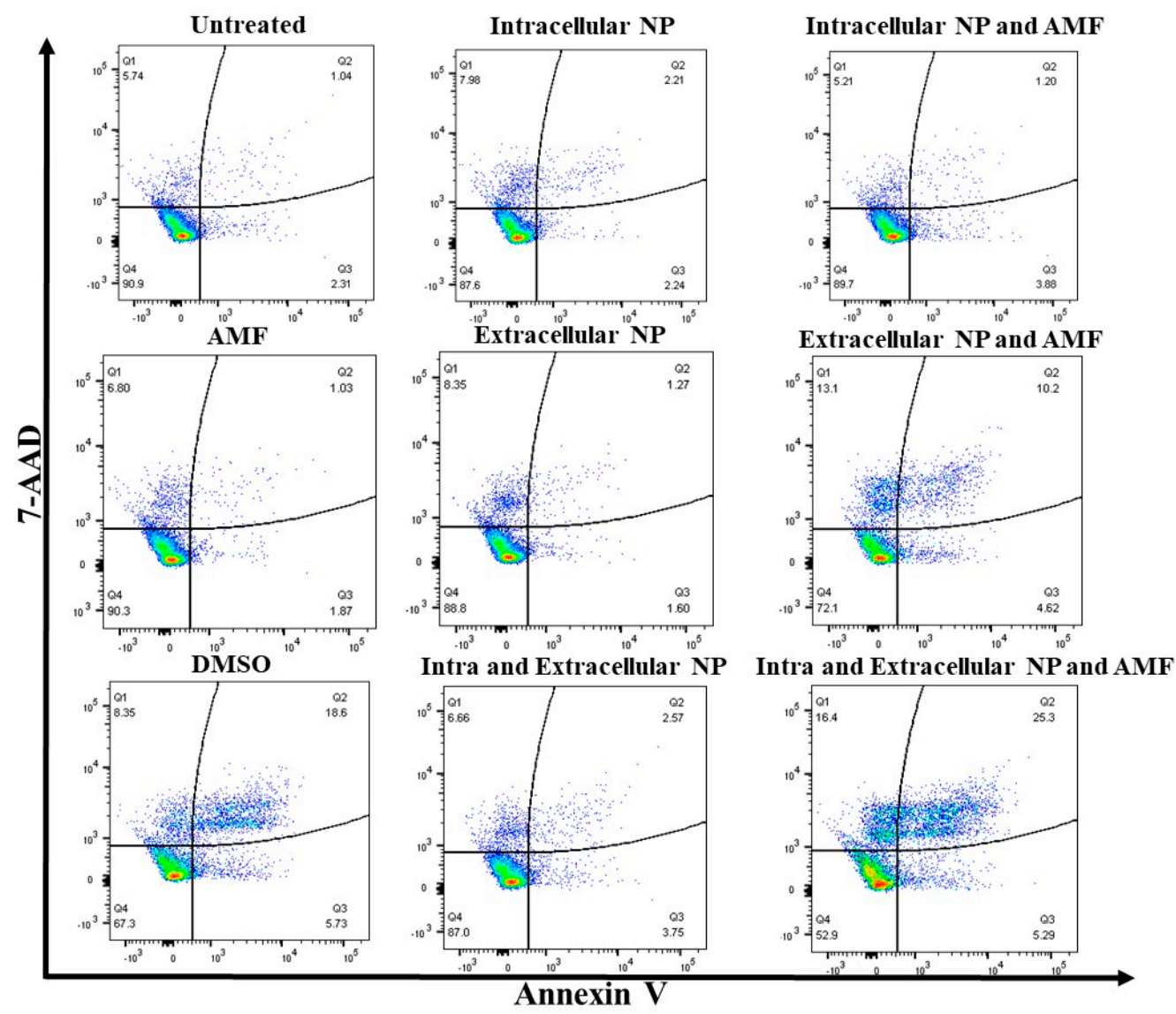

B

BxPC-3 viability count

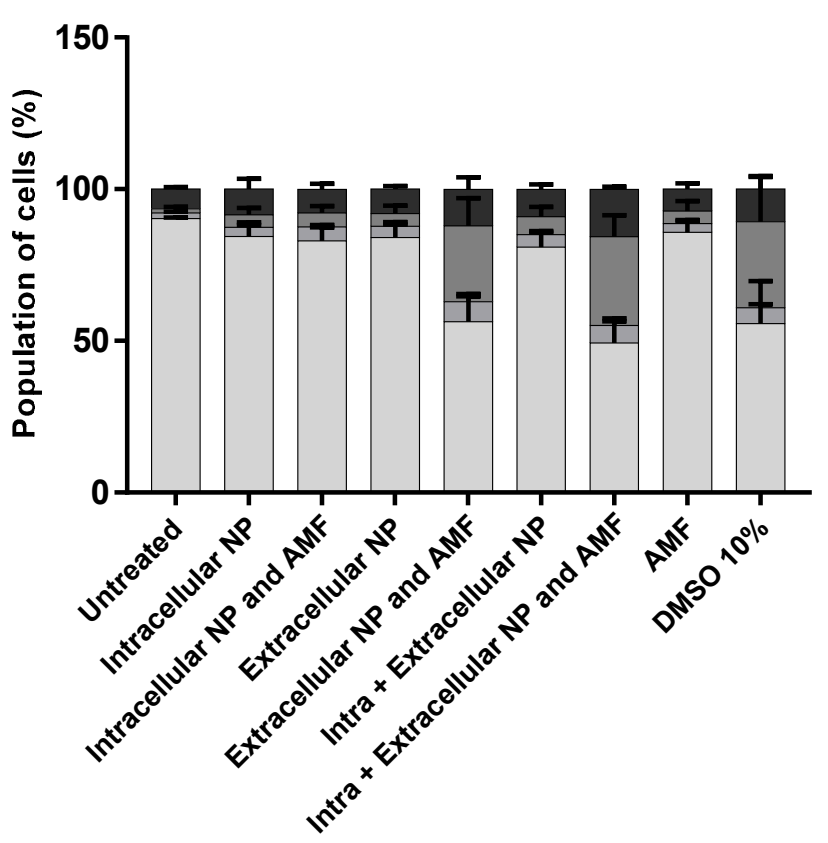

Necrotic

Late apoptotic

Early apoptotic

Vital

Figure 7. Cont. 
C

\begin{tabular}{|c|c|c|c|c|c|c|c|c|}
\hline $\begin{array}{c}\text { Viability } \\
\text { against } \\
\text { untreated }\end{array}$ & $\begin{array}{c}\text { Intra } \\
\text { NP }\end{array}$ & $\begin{array}{c}\text { Intra NP } \\
+ \text { AMF }\end{array}$ & $\begin{array}{c}\text { Extra } \\
\text { NP }\end{array}$ & $\begin{array}{c}\text { Extra } \\
\text { NP+ } \\
\text { AMF }\end{array}$ & $\begin{array}{c}\text { Intra + } \\
\text { Extra NP }\end{array}$ & $\begin{array}{c}\text { Intra + } \\
\text { Extra NP + } \\
\text { AMF }\end{array}$ & AMF & DMSO \\
\hline Vital & $\mathrm{ns}$ & $\mathrm{ns}$ & $\mathrm{ns}$ & $* * * *$ & $*$ & $* * * *$ & $\mathrm{~ns}$ & $* * * *$ \\
\hline $\begin{array}{c}\text { Early } \\
\text { Apoptosis }\end{array}$ & $\mathrm{ns}$ & $\mathrm{ns}$ & $\mathrm{ns}$ & $\mathrm{ns}$ & $\mathrm{ns}$ & $\mathrm{ns}$ & $\mathrm{ns}$ & $\mathrm{ns}$ \\
\hline $\begin{array}{c}\text { Late } \\
\text { Apoptosis }\end{array}$ & $\mathrm{ns}$ & $\mathrm{ns}$ & $\mathrm{ns}$ & $* * * *$ & $\mathrm{~ns}$ & $* * * *$ & $\mathrm{~ns}$ & $* * * *$ \\
\hline Necrosis & $\mathrm{ns}$ & $\mathrm{ns}$ & $\mathrm{ns}$ & $\mathrm{ns}$ & $\mathrm{ns}$ & $*$ & $\mathrm{~ns}$ & $\mathrm{~ns}$ \\
\hline
\end{tabular}

\begin{tabular}{|c|c|}
\hline $\begin{array}{c}\text { Viability } \\
\text { against } \\
\text { Extra NP }\end{array}$ & $\begin{array}{c}\text { Extra NP } \\
+ \text { AMF }\end{array}$ \\
\hline Vital & $* * * *$ \\
\hline $\begin{array}{c}\text { Early } \\
\text { apoptosis }\end{array}$ & $\mathrm{ns}$ \\
\hline $\begin{array}{c}\text { Late } \\
\text { apoptosis } \\
\text { Necrosis }\end{array}$ & $* * * *$ \\
\hline
\end{tabular}

E

\begin{tabular}{|c|c|}
\hline $\begin{array}{c}\text { Viability } \\
\text { against Intra } \\
\text { NP }\end{array}$ & $\begin{array}{c}\text { Intra NP + } \\
\text { AMF }\end{array}$ \\
\hline Vital & ns \\
\hline $\begin{array}{c}\text { Early } \\
\text { apoptosis }\end{array}$ & $n s$ \\
\hline $\begin{array}{c}\text { Late } \\
\text { apoptosis }\end{array}$ & $n s$ \\
\hline Necrosis & $\mathrm{ns}$ \\
\hline
\end{tabular}

\begin{tabular}{|c|c|}
\hline $\begin{array}{c}\text { Viability } \\
\text { against Intra } \\
\text { +extra NP }\end{array}$ & $\begin{array}{c}\text { Intra + } \\
\text { extra NP+ } \\
\text { AMF }\end{array}$ \\
\hline Vital & $* * * *$ \\
\hline $\begin{array}{c}\text { Early } \\
\text { apoptosis }\end{array}$ & $\mathrm{ns}$ \\
\hline $\begin{array}{c}\text { Late } \\
\text { apoptosis }\end{array}$ & $* * * *$ \\
\hline Necrosis & $\mathrm{ns}$ \\
\hline
\end{tabular}

Figure 7. Viability of BxPC-3 cells after in vitro magnetic hyperthermia. (A) Representative flow experiment depicting Annexin $\mathrm{V}^{+} / 7-\mathrm{AAD}^{-}$(early apoptotic), Annexin $\mathrm{V}^{+} / 7-\mathrm{AAD}^{+}$(late apoptotic), $7-\mathrm{AAD}^{+}$(necrotic), and Annexin $\mathrm{V}^{-} / 7-\mathrm{AAD}^{-}$(vital) cells in each treatment group. (B) Graph comparing populations of vital, early apoptotic, late apoptotic, and necrotic cells in each treatment group. Results are from six individual experiments with 10,000 events recorded for each. Error bars = standard deviation. Abbreviations: NP, nanoparticle; Intra, intracellular; Extra, extracellular; AMF, alternating magnetic field. (C) Table describing significant differences in vital, early apoptotic, late apoptotic and necrotic cells from each treatment group against untreated cells. (D-F) Tables describing significant differences of these same cellular populations with nanoparticles exposed to AMF versus nanoparticles alone. Results are from six individual experiments with 10,000 events recorded for each. Abbreviations: NS, not significant; NP, nanoparticle; Intra, intracellular; Extra, extracellular; AMF, alternating magnetic field. Analysed using two-way ANOVA followed by Tukey's test for multiple comparisons. * $p<0.05$. **** $p<0.0001$.

\subsection{Caspase Activity}

Differences in caspase activity were negligible in all treatment groups except for the positive control (Figure 8). Pairing this with the flow cytometry data suggests that the primary mechanism of cell death in this case was necrosis, as the cells stained positive for both Annexin and 7-AAD following extracellular magnetic hyperthermia treatment. 


\section{Caspase activation}

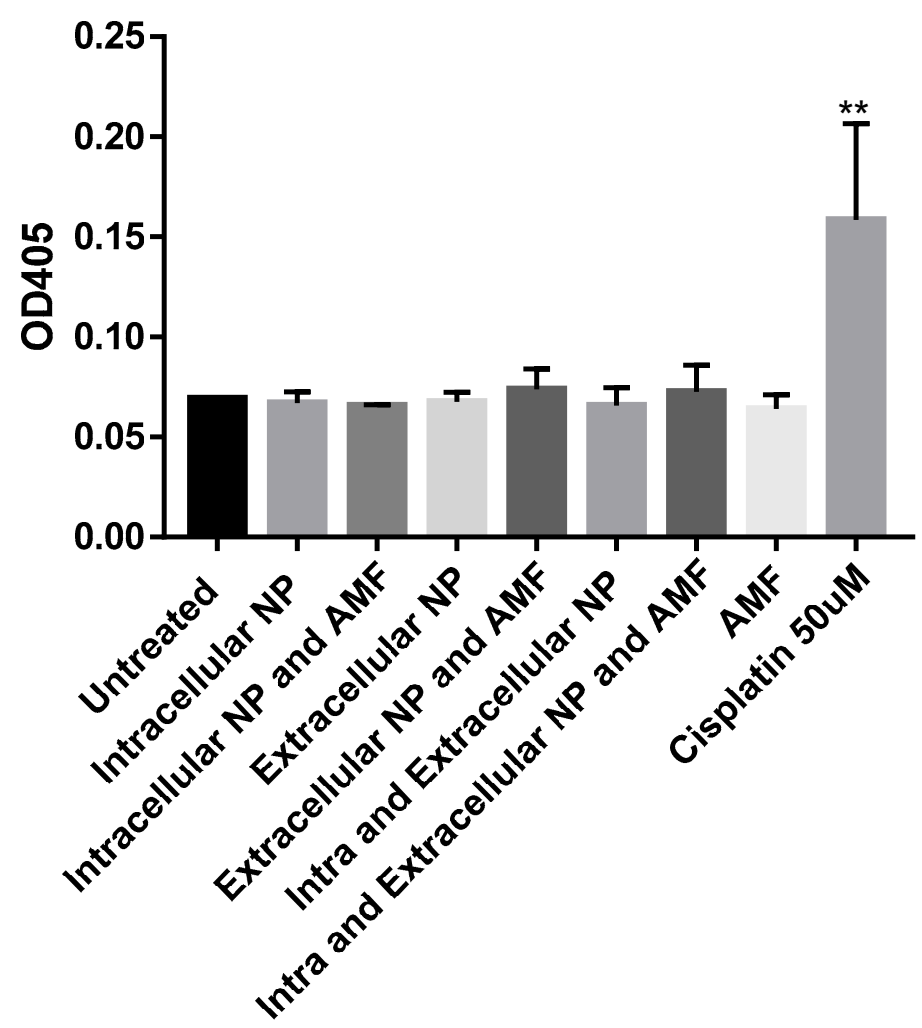

Figure 8. Caspase activation with BxPC-3 cells following magnetic hyperthermia treatment. Results are from four individual experiments, of which two experiments are pooled together to get the desired concentration of protein required for the assay. Values are a result of absorptions at $405 \mathrm{~nm}$. Significance is against the untreated. Significance was assessed using one-way ANOVA followed by Dunnett's test. Abbreviations: NP, nanoparticle; Intra, intracellular; Extra, extracellular; AMF, alternating magnetic field. Error bars $=$ standard deviation. ${ }^{* *} p<0.01$.

\section{Discussion}

FluidMAG/C11-D nanoparticles were characterized and assessed for their heating capabilities in response to an AMF of $35 \mathrm{mT}$ at $92 \mathrm{kHz}$. The nanoparticles were deemed to have no effect on viability of BxPC-3 cells at concentrations up to $200 \mu \mathrm{g} / \mathrm{mL}$ in vitro using multiparametric analysis and so this concentration was used to evaluate their uptake into the cells. ICP-OES demonstrated that an average of $12.8 \pm 3.6 \mathrm{pg}$ Fe was internalised into each cell (with $12.8 \mathrm{pg}$ Fe equating to 16,487 nanoparticles) and subsequent Prussian blue staining confirmed this internalisation and identified the nanoparticles propensity to accumulate around the nuclear membrane. This level of iron uptake into cells is comparable to the results reported from similar protocols published previously [35-37]. Next, intracellular hyperthermia, extracellular hyperthermia, and intracellular and extracellular hyperthermia were compared to define differences in viability through Annexin V/7-AAD staining. Intracellular hyperthermia showed no change in viability against the untreated, whereas cells exposed to extracellular nanoparticles and magnetic fields underwent significant apoptosis/necrosis (staining positively for both Annexin $\mathrm{V}$ and 7-AAD) against untreated cells and nanoparticle treated cells alone. This result was similar to that reported in Ludwig et al for BxPC-3 cells [31].

Cells that stain positively for 7-AAD have a permeabilised cellular membrane characteristic of cells that have undergone late apoptosis or necrosis, which allows 7-AAD to become internalised and intercalate to guanine and cytosine regions of DNA [38]. By contrast, Annexin V relies on the extracellular exposure of phosphatidyl serine (PS) from the plasma membrane-which normally faces internally in healthy cells-where it binds to PS in a calcium-dependant manner, acting as a positive 
early stain for apoptosis [39]. These two mechanisms of cell death can overlap if the cells undergoing apoptosis do not get phagocytosed, and so enter a stage of secondary necrosis which shares many features of primary necrosis $[40,41]$. In order to distinguish the primary mechanism of cell death following hyperthermia, caspase- 3 activity was evaluated using colourimetric assay. Caspase- 3 activity is essential for efficient apoptosis and so its expression levels against the untreated will indicate if apoptosis is occurring or not [42]. No changes in caspase-3 activity were identified following magnetic hyperthermia and so necrosis was deemed the primary mechanism of cell death in this case. This strong population of necrotic cells was also observed in the above-mentioned Ludwig et al. [31].

As intracellular magnetic hyperthermia resulted in no change in viability, this leads to questions over its relevance to this treatment as a whole. IONP internalised into cells experience an inhibition of Brownian motion and therefore heating capability $[17,43]$. Therefore, the efficacy observed with this treatment in vivo and the clinic may be solely due to extracellular nanoparticles as they are the primary source for temperature elevations in the tumour. Importantly, this has implications for IONP design and whether efforts to improve the internalisation of these nanoparticles through functionalisation with targeting agents are necessary. Nonetheless, further studies are needed to elucidate whether intracellular nanoparticles can contribute to treatment efficacy in alternative ways such as instigating anti-tumour immune responses or disrupting intracellular signalling pathways that may enhance the effects of combination therapies, as magnetic hyperthermia has been reported to do [44,45].

\section{Conclusions}

The effect of intracellular and extracellular magnetic hyperthermia on the viability of BxPC-3 cells was compared after a $30 \mathrm{~min}$ treatment. It was found that extracellular magnetic hyperthermia (at temperatures of $41.2 \pm 0.6^{\circ} \mathrm{C}$ ) could induce significant levels of necrosis in these cells whereas intracellular magnetic hyperthermia showed no effect on viability. This therefore led to questions on the overall influence of intracellular IONP to treatment efficacy and whether they are necessary to achieve desired therapeutic effects. It is not yet known whether intracellular IONP plays a role in alternative anti-tumour effects such as stimulating anti-tumour immune responses or inducing alterations to intracellular signalling reported to be involved in magnetic hyperthermia treatment efficacy; therefore, future work is required to clarify this role. This research may provide indications for IONP design for magnetic hyperthermia applications in the future.

Supplementary Materials: The following are available online at http://www.mdpi.com/2079-4991/10/3/593/s1, Figure S1: Nanoparticle tracking analysis, dynamic light scattering and transmission electron microscopy graphs for fluidMAG/C11-D, Figure S2: Nanoparticle shows little interference with APC or PerCP-Cy5.5 channels, Figure S3: Gating strategy for BxPC-3 cells, Figure S4: Annexin V/7-AAD staining of cells treated with incubator hyperthermia $\left(42.5^{\circ} \mathrm{C}\right.$ for $\left.30 \mathrm{~min}\right)$ versus untreated.

Author Contributions: G.H. provided the research methodology for the study, generated data and wrote the first draft of the manuscript; A.B. was involved in data curation and reviewing the manuscript; A.P.-M. reviewed the manuscript and acquired funding for the study; Y.V. reviewed the manuscript and acquired funding for the study. All authors have read and agreed to the published version of the manuscript.

Funding: This research was funded by NoCanTher (grant agreement: 685795) and the Irish Research Council (project identifier: GOIPG/2016/1629).

Acknowledgments: The authors would like to thank the CRANN advanced microscopy laboratory for training and use of the transmission electron microscope. Additionally, we would like to duly acknowledge John Cassidy from the chemical and pharmaceutical school at the Technological University of Dublin for the training and use of the ICP-OES and AAS.

Conflicts of Interest: The authors have nothing to declare. 


\section{References}

1. Ansari, M.O.; Ahmad, M.F.; Shadab, G.G.H.A.; Siddique, H.R. Superparamagnetic iron oxide nanoparticles based cancer theranostics: A double edge sword to fight against cancer. J. Drug Deliv. Sci. Technol. 2018, 45, 177-183. [CrossRef]

2. Rosen, J.; Chan, L.; Shieh, D.-B.; Gu, F. Iron oxide nanoparticles for targeted cancer imaging and diagnostics. Nanomed. Nanotechnol. Biol. Med. 2012, 8, 275-290. [CrossRef] [PubMed]

3. Das, P.; Colombo, M.; Prosperi, D. Recent advances in magnetic fluid hyperthermia for cancer therapy. Colloids Surf. B Biointerfaces 2019, 174, 42-55. [CrossRef] [PubMed]

4. Kaur, P.; Aliru, M.L.; Chadha, A.S.; Asea, A.; Krishnan, S. Hyperthermia using nanoparticles-Promises and pitfalls. Int. J. Hyperthermia 2016, 32, 76-88. [CrossRef]

5. Chang, D.; Lim, M.; Goos, J.A.; Qiao, R.; Ng, Y.Y.; Mansfeld, F.M.; Jackson, M.; Davis, T.P.; Kavallaris, M. Biologically Targeted Magnetic Hyperthermia: Potential and Limitations. Front. Pharmacol. 2018, 9, 831. [CrossRef]

6. Hedayatnasab, Z.; Abnisa, F.; Daud, W.M.A.W. Review on magnetic nanoparticles for magnetic nanofluid hyperthermia application. Mater. Des. 2017, 123, 174-196. [CrossRef]

7. Ortega, D.; Pankhurst, Q. Magnetic Hyperthermia. Nanoscience 2013, 1, e88.

8. Kuncser, A.; Iacob, N.; Kuncser, V. On the relaxation time of interacting superparamagnetic nanoparticles and implications for magnetic fluid hyperthermia. Beilstein J. Nanotechnol. 2019, 10, 1280-1289. [CrossRef]

9. Périgo Élio, A.; Hemery, G.; Sandre, O.; Ortega, D.; Garaio, E.; Plazaola, F.; Teran, F.J. Fundamentals and advances in magnetic hyperthermia. Appl. Phys. Rev. 2015, 2, 041302. [CrossRef]

10. Dennis, C.L.; Ivkov, R. Physics of heat generation using magnetic nanoparticles for hyperthermia. Int. J. Hyperthermia 2013, 29, 715-729. [CrossRef]

11. Shaterabadi, Z.; Nabiyouni, G.; Soleymani, M. Physics responsible for heating efficiency and self-controlled temperature rise of magnetic nanoparticles in magnetic hyperthermia therapy. Prog. Biophys. Mol. Biol. 2018, 133, 9-19. [CrossRef] [PubMed]

12. Gilchrist, R.K.; Medal, R.; Shorey, W.D.; Hanselman, R.C.; Parrott, J.C.; Taylor, C.B. Selective inductive heating of lymph nodes. Ann. Surg. 1957, 146, 596-606. [CrossRef] [PubMed]

13. Gilchrist, R.K.; Shorey, W.D.; Hanselman, R.C.; Depeyster, F.A.; Yang, J.; Medal, R. Effects of electromagnetic heating on internal viscera: A preliminary to the treatment of human tumors. Ann. Surg. 1965, 161, 890-896. [CrossRef] [PubMed]

14. Luo, S.; Wang, L.F.; Ding, W.J.; Wang, H.; Zhou, J.M.; Jin, H.K.; Su, S.F.; Ouyang, W.W. Clinical trials of magnetic induction hyperthermia for treatment of tumours. OA Cancer 2014, 18, 1-6.

15. MagForce. Available online: https://www.magforce.com/home/ (accessed on 23 March 2020).

16. Kossatz, S.; Grandke, J.; Couleaud, P.; Latorre, A.; Aires, A.; Crosbie-Staunton, K.; Ludwig, R.; Dähring, H.; Ettelt, V.; Lazaro-Carrillo, A.; et al. Efficient treatment of breast cancer xenografts with multifunctionalized iron oxide nanoparticles combining magnetic hyperthermia and anti-cancer drug delivery. Breast Cancer Res. $B C R$ 2015, 17, 66. [CrossRef] [PubMed]

17. Sanhaji, M.; Göring, J.; Couleaud, P.; Aires, A.; Cortajarena, A.L.; Courty, J.; Prina-Mello, A.; Stapf, M.; Ludwig, R.; Volkov, Y.; et al. The phenotype of target pancreatic cancer cells influences cell death by magnetic hyperthermia with nanoparticles carrying gemicitabine and the pseudo-peptide NucAnt. Nanomed. Nanotechnol. Biol. Med. 2019, 20, 101983. [CrossRef]

18. Maguire, C.M.; Sillence, K.; Roesslein, M.; Hannell, C.; Suarez, G.; Sauvain, J.J.; Capracotta, S.; Contal, S.; Cambier, S.; El Yamani, N.; et al. Benchmark of Nanoparticle Tracking Analysis on Measuring Nanoparticle Sizing and Concentration. J. Micro Nano-Manuf. 2017, 5, 041002. [CrossRef]

19. Hole, P.; Sillence, K.; Hannell, C.; Maguire, C.M.; Roesslein, M.; Suarez, G.; Capracotta, S.; Magdolenova, Z.; Horev-Azaria, L.; Dybowska, A.; et al. Interlaboratory comparison of size measurements on nanoparticles using nanoparticle tracking analysis (NTA). J. Nanopart. Res. 2013, 15, 2101. [CrossRef]

20. Maguire, C. Particle Tracking Analysis. 2018. Available online: http://www.euncl.eu/about-us/assay-cascade/ PDFs/PCC/EUNCL_PCC_023.pdf?m=1526712237\& (accessed on 23 March 2020).

21. Calzolai, L. Measuring Batch Mode DLS. 2015. Available online: http://www.euncl.eu/about-us/assaycascade/PDFs/Prescreening/EUNCL-PCC-001.pdf?m=1468937875\& (accessed on 23 March 2020).

22. Kallumadil, M.; Tada, M.; Nakagawa, T.; Abe, M.; Southern, P.; Pankhurst, Q.A. Suitability of commercial colloids for magnetic hyperthermia. J. Magn. Magn. Mater. 2009, 321, 1509-1513. [CrossRef] 
23. Gao, C.; Ding, Y.; Zhong, L.; Jiang, L.; Geng, C.; Yao, X.; Cao, J. Tacrine induces apoptosis through lysosomeand mitochondria-dependent pathway in HepG2 cells. Toxicol. In Vitro 2014, 28, 667-674. [CrossRef]

24. Dise, C.A.; Goodman, D.B. The relationship between valinomycin-induced alterations in membrane phospholipid fatty acid turnover, membrane potential, and cell volume in the human erythrocyte. J. Biol. Chem. 1985, 260, 2869-2874. [PubMed]

25. Klein, B.; Wörndl, K.; Lütz-Meindl, U.; Kerschbaum, H.H. Perturbation of intracellular K+ homeostasis with valinomycin promotes cell death by mitochondrial swelling and autophagic processes. Apoptosis 2011, 16, 1101. [CrossRef] [PubMed]

26. Calero, M.; Chiappi, M.; Lazaro-Carrillo, A.; Rodríguez, M.J.; Chichón, F.J.; Crosbie-Staunton, K.; Prina-Mello, A.; Volkov, Y.; Villanueva, Á.; Carrascosa, J.L. Characterization of interaction of magnetic nanoparticles with breast cancer cells. J. Nanobiotechnol. 2015, 13, 16. [CrossRef] [PubMed]

27. Prina-Mello, A.; Crosbie-Staunton, K.; Salas, G.; Morales, M.D.P.; Volkov, Y. Multiparametric Toxicity Evaluation of SPIONs by High Content Screening Technique: Identification of Biocompatible Multifunctional Nanoparticles for Nanomedicine. IEEE Trans. Magn. 2013, 49, 377-382. [CrossRef]

28. Miyamoto, R.; Oda, T.; Hashimoto, S.; Kurokawa, T.; Inagaki, Y.; Shimomura, O.; Ohara, Y.; Yamada, K.; Akashi, Y.; Enomoto, T.; et al. Cetuximab delivery and antitumor effects are enhanced by mild hyperthermia in a xenograft mouse model of pancreatic cancer. Cancer Sci. 2016, 107, 514-520. [CrossRef]

29. Hilger, I. In vivo applications of magnetic nanoparticle hyperthermia. Int. J. Hyperthermia 2013, 29, 828-834. [CrossRef]

30. Blanco-Andujar, C.; Ortega, D.; Southern, P.; Nesbitt, S.A.; Thanh, N.T.; Pankhurst, Q.A. Real-time tracking of delayed-onset cellular apoptosis induced by intracellular magnetic hyperthermia. Nanomedicine 2016, 11, 121-136. [CrossRef]

31. Ludwig, R.; Teran, F.J.; Teichgraeber, U.; Hilger, I. Nanoparticle-based hyperthermia distinctly impacts production of ROS, expression of Ki-67, TOP2A, and TPX2, and induction of apoptosis in pancreatic cancer. Int. J. Nanomed. 2017, 12, 1009-1018. [CrossRef]

32. Rego, G.N.A.; Mamani, J.B.; Souza, T.K.F.; Nucci, M.P.; Da Silva, H.R.; Gamarra, L.F. Therapeutic evaluation of magnetic hyperthermia using Fe3O4-aminosilane-coated iron oxide nanoparticles in glioblastoma animal model. Einstein (Sao Paulo) 2019, 17, eAO4786. [CrossRef]

33. Asin, L.; Ibarra, M.R.; Tres, A.; Goya, G.F. Controlled Cell Death by Magnetic Hyperthermia: Effects of Exposure Time, Field Amplitude, and Nanoparticle Concentration. Pharm. Res. 2012, 29, 1319-1327. [CrossRef]

34. Oh, Y.; Lee, N.; Kang, H.W. In vitro study on apoptotic cell death by effective magnetic hyperthermia with chitosan-coated MnFe2O4. Nanotechnology 2016, 27, 115101. [CrossRef] [PubMed]

35. Poller, J.M.; Zaloga, J.; Schreiber, E.; Unterweger, H.; Janko, C.; Radon, P.; Eberbeck, D.; Trahms, L.; Alexiou, C.; Friedrich, R.P. Selection of potential iron oxide nanoparticles for breast cancer treatment based on in vitro cytotoxicity and cellular uptake. Int. J. Nanomed. 2017, 12, 3207-3220. [CrossRef] [PubMed]

36. Ma, W.; Xie, Q.; Zhang, B.; Chen, H.; Tang, J.; Lei, Z.; Wu, M.; Zhang, D.; Hu, J. Neural Induction Potential and MRI of ADSCs Labeled Cationic Superparamagnetic Iron Oxide Nanoparticle In Vitro. Contrast Media Mol. Imaging 2018, 2018, 6268437. [CrossRef] [PubMed]

37. Su, L.; Zhang, B.; Huang, Y.; Fan, Z.; Zhao, Y. Enhanced cellular uptake of iron oxide nanoparticles modified with 1,2-dimyristoyl-sn-glycero-3-phosphocholine. RSC Adv. 2017, 7, 38001-38007. [CrossRef]

38. Zembruski, N.C.; Stache, V.; Haefeli, W.E.; Weiss, J. 7-Aminoactinomycin D for apoptosis staining in flow cytometry. Anal. Biochem. 2012, 429, 79-81. [CrossRef] [PubMed]

39. Fadok, V.A.; Bratton, D.L.; Frasch, S.C.; Warner, M.L.; Henson, P.M. The role of phosphatidylserine in recognition of apoptotic cells by phagocytes. Cell Death Differ. 1998, 5, 551-562. [CrossRef]

40. Berghe, T.V.; Vanlangenakker, N.; Parthoens, E.; Deckers, W.; Devos, M.; Festjens, N.; Guerin, C.J.; Brunk, U.T.; Declercq, W.; Vandenabeele, P. Necroptosis, necrosis and secondary necrosis converge on similar cellular disintegration features. Cell Death Differ. 2009, 17, 922. [CrossRef]

41. Krysko, D.V.; Berghe, T.V.; D’Herde, K.; Vandenabeele, P. Apoptosis and necrosis: Detection, discrimination and phagocytosis. Methods 2008, 44, 205-221. [CrossRef]

42. Porter, A.G.; Jänicke, R.U. Emerging roles of caspase-3 in apoptosis. Cell Death Differ. 1999, 6, 99-104. [CrossRef]

43. Ludwig, R.; Stapf, M.; Dutz, S.; Müller, R.; Teichgräber, U.; Hilger, I. Structural properties of magnetic nanoparticles determine their heating behavior-An estimation of the in vivo heating potential. Nanoscale Res. Lett. 2014, 9, 602. [CrossRef] 
44. Ludwig, R.; Stapf, M.; Dutz, S.; Müller, R.; Teichgräber, U.; Hilger, I. Combined Magnetic Hyperthermia and Immune Therapy for Primary and Metastatic Tumor Treatments. ACS Nano 2020, 14, 1033-1044.

45. Chen, L.; Chen, C.; Wang, P.; Song, T. Mechanisms of Cellular Effects Directly Induced by Magnetic Nanoparticles under Magnetic Fields. J. Nanomater. 2017, 2017, 1564634. [CrossRef]

(C) 2020 by the authors. Licensee MDPI, Basel, Switzerland. This article is an open access article distributed under the terms and conditions of the Creative Commons Attribution (CC BY) license (http://creativecommons.org/licenses/by/4.0/). 